\title{
Interpretacje
}

\section{Dzika natura Mirona Białoszewskiego}

Agnieszka Karpowicz

TEKSTY DRUGIE 2018, NR 2, S. 166-185

DOI: $10.18318 /$ td.2018.2.11

\section{Zanikające krajobrazy}

Jedną z praktyk najczęściej opisywanych przez Mirona Białoszewskiego w utworach z późnego, „lizbońskiego”, okresu twórczości, rozpoczynającego się w 1975 roku przeprowadzką ze śródmiejskiego placu Dąbrowskiego na mało zurbanizowany wtedy teren warszawskiej Pragi Południe ${ }^{1}$, jest jeżdżenie po „zielska”2 na obrzeża miasta

1 Praga Południe to budząca do dziś kontrowersje czysto administracyjna nazwa, wprowadzona po II wojnie światowej i funkcjonująca w czasach, w których mieszkał tu Białoszewski. Na mocy tej decyzji w skład nieistniejącej wcześniej dzielnicy weszły odrębne historycznie osiedla niezwiązane też ze starą Pragą Północ, co sugerowałaby nazwa. Według współczesnego podziału administracyjnego Warszawy w jej skład wchodzą osiedla: Kamionek, Saska Kępa, Gocław, Gocławek, Przyczółek Grochowski, Grochów (Centrum, Południe, Północ, Grochów-Kinowa) i Olszynka Grochowska, stanowiące główne kierunki eksploracji Białoszewskiego w okresie "lizbońskim".

2 M. Białoszewski Chamowo, PIW, Warszawa 2008, s. 68, 110 i in. (określenie to pojawia się w Chamowie wielokrotnie). Dalej cytaty z tego wydania oznaczam w tekście głównym, podając w nawiasie skrót "C" i numer strony. Korzystam z wydania z 2008 roku, ponieważ w moich 
lub na półwiejskie, nadwiślańskie Siekierki ${ }^{3}$ i chodzenie po okolicznych, np. gocławskich lub grochowskich, łąkach i zaroślach. Zbieranie chwastów, traw, dziko rosnących kwiatów i komponowanie z nich bukietów to częsty i ważny temat zarówno wierszy Białoszewskiego (np. cykl Siekierki, Rwanie piękności) z lat 70. XX wieku, jak i pisanego wtedy Tajnego dziennika czy Chamowa, ale też Dziennika we dwoje Jadwigi Stańczakowej, niewidomej przyjaciółki pisarza mieszkającej przy ulicy Hożej, która była wtedy na różne sposoby przez niego $\mathrm{w}$ tę praktykę angażowana.

Jeżdżąc po „zielska”, Białoszewski obserwuje i odnotowuje zanikające krajobrazy prawobrzeżnej Warszawy, zarówno na jej przedmieściach, jak i w najbliższym otoczeniu Pragi Południe ${ }^{4}$. Po roku od przeprowadzki na ulicę Lizbońską pisze: „Gdzie te niezamierzone nieużytki z dzikimi kwiatami? Kilometry ostów. Siwe i złe. Jak stare baby. Nie ma ich. Siekierki pomniejszone" (C, 385). Dzikie, zarośnięte zielenią tereny, które eksplorował, były właśnie zagospodarowywane zgodnie z urbanizacyjno-modernizacyjnym projektem rozwoju stolicy oraz jej rosnącymi potrzebami mieszkaniowymi:

badaniach opierałam się również na nagraniach magnetofonowych, stanowiących podstawę także drugiej, uzupełnionej i poszerzonej edycji. Uzupełnienia w drugim, poprawionym wydaniu nie wnoszą też według mnie znaczących treści do wątku kwiatowo-roślinnego.

3 O roli Siekierek w twórczości Białoszewskiego pisałam szerzej w tekście Miejsce osobne. Sprawdzanie Siekierek: patrzenie, chodzenie, słuchanie, w: „Tętno pod tynkiem”. Warszawa Mirona Białoszewskiego, red. A. Karpowicz, P. Kubkowski, W. Pessel, I. Piotrowski, Lampa i Iskra Boża, seria Topo-Grafie, t. 1, Warszawa 2013.

4 Zapisy te są wręcz wnikliwą obserwacją antropologiczną przemian tej dzielnicy w latach 70. XX wieku, doskonale korespondującą z materiałami prasowymi i ikonograficznymi z tamtej epoki. Dlatego też stały się one podstawą opowieści o historii Pragi Południe podczas wystawy literackiej "Znikające krajobrazy. Opowieści przestrzenne Mirona Białoszewskiego" w Muzeum Warszawskiej Pragi, pod opieką kuratorską moją i Aleksandry Duralskiej (czerwiec-październik 2016 roku). W tekście korzystam również z wyników tych kwerend. Narracja Chamowa okazała się jednocześnie obserwacją dynamicznych procesów modernizacyjnych tamtego czasu, zaskakująco zbieżną z oddolnymi wspomnieniami i fotografiami prywatnymi mieszkańców tych okolic (na temat procesów modernizacyjnych w opowieści Białoszewskiego zob. np. A. Karpowicz "Domy tu się nie przyjmują". Trzy spotkania na rondzie Wiatraczna, w: Refleksja humanistyczna w planowaniu przestrzennym, red. A. Wójtowicz, Wydawnictwo IBL PAN, Warszawa 2018 [w druku]). Już sama możliwość przygotowania takiej wystawy, ale też służące jej kwerendy archiwalne dowiodły, że również późne utwory literackie poety są mocno zakorzenione w konkretnej i realnej przestrzeni miejskiej, będącej jednocześnie przestrzenią biograficzną, a ponadto jej historia jest Białoszewskiemu bardzo dobrze znana i stanowi integralną część jego wypowiedzi artystycznej. 
Spojrzałem na wygolone traktorami pola za pawilonem z barem mlecznym i sklepami, bliskie już dawno, chociaż tak niedawno szedłem przez bodiaki, wertepy i błota tego pola. Teraz goło, znanie. Dobrze, że zostawili jędzowate wierzby, które zostały tu jako twarde świadki uroczyska. (C, s. 324)

"Cywilizowanie" i unowocześnianie tych dzikich - wedle określenia Białoszewskiego - terenów odbywało się m.in. przez zakładanie tu osiedli mieszkaniowych wraz z charakterystycznymi dla tego okresu wielopiętrowymi blokami z wielkiej płyty, m.in. tym przy ulicy Lizbońskiej, w którym poeta zamieszkał ${ }^{5}$. Naturalnym kierunkiem ekspansji miasta była właśnie ta część prawobrzeżnej Warszawy, znajdująca się stosunkowo blisko centrum, ale posiadająca jeszcze wtedy - poza mającą już długie tradycje miejskie Pragą Północ oraz elegancką Saską Kępą (to w jej okolicach Białoszewski kupuje najczęściej kwiaty w kwiaciarniach, co dobrze podkreśla jej wytworny charakter) zmodernizowaną i zabudowywaną już w okresie międzywojennym, podobnie jak niewielka część Grochowa - wciąż charakter bardziej wiejski, a miejscami małomiasteczkowy, co również Białoszewski czujnie odnotowuje: „Wydostałem się między kamieniczkami i chwastami na plac Szembeka. Zupełnie jakbym wdepnął do nieznanego miasta. Miasteczka. Rynek. Zielska dzikie (C, 110).

Znikanie roślinnych krajobrazów miejskich jest w Chamowie odnotowywane i staje się wręcz kanwą konceptualnego z ducha zamysłu konstrukcyjnego: narrator często wraca w te same miejsca po roku, porównuje doświadczenia i pejzaże, odnotowuje zmiany. Wraz z przyzwyczajaniem się (choć nigdy do końca) do nowej okolicy widoki i doświadczenia tracą intensywność, moc wywoływania poszukiwanych przez Białoszewskiego zaskoczeń i niespodzianek, a jednocześnie logiką zmian rządzi kurczenie się, znikanie i zanikanie, jakby wszystkiego było coraz mniej: zabudowywanych widoków z okna, horyzontu ograniczanego kolejnymi wysokościowcami, zawężającego się pola widzenia, zieleni, bujnego, karczowanego właśnie roślinnego życia, drzew: „Dużo drzew marnieje. Nie wiem, czy to od spalin, czy taki rok” (C, 384).

5 Ważnym tematem w tym okresie twórczości jest oczywiście także doświadczenie bloku i blokowiska, które w tym miejscu pomijam. Zob. m.in. J. Grądziel-Wójcik „Święte życie” na Lizbońskiej. Architektura i sacrum w poezji Mirona Białoszewskiego „ "Poznańskie Studia Językoznawcze” 2015 nr 30; A. Karpowicz Proza życia, Wydawnictwa UW, Warszawa 2012 (rozdziały poświęcone Białoszewskiemu); P. Kubkowski Mirona Białoszewskiego "blokowanie": przestrzenie, obrazy, dźwięki, w: „Tętno pod tynkiem”...; E. Rybicka „Blokowidła” Mirona Białoszewskiego, czyli terapia wierszem, "Autoportret" $2005 \mathrm{nr} 4$. 
Klamrę stanowi tu np. likwidacja lotniska na Gocławiư, w początkowych partiach tekstu denerwującego narratora intensywnością dźwięków:

Już od pewnego czasu zauważyłem lekkie zmiany w lewym widoku z okna. Tylko nie wiedziałem o co chodzi. [...]

- Lotnisko skasują, i to już. Już wdzierają się od Ostrobramskiej, walcują ziemię. Tam powstanie wielkie osiedle.

To między najbliższą wsią za działkami a rajem. Raj przepadnie. $(\mathrm{C}, 382)$

Zanikające krajobrazy są tu również przestrzenną, miejską ekstensją sytuacji egzystencjalnej autora-narratora: rok na „Chamowie” to również autoetnografia ${ }^{7}$ jego choroby, starzenia się, pogranicznego usytuowania między życiem i śmiercią, powolnego odchodzenia ${ }^{8}$. W typowy dla Białoszewskiego sposób między miastem a nim samym, również w sensie biologicznym, cielesnym, zachodzi przenikanie i współodczuwanie, jedno jest medium opowieści o drugim: biografia miasta biografii pisarza i odwrotnie, przy czym charakterystyka topograficzna i historia konkretnej przestrzeni zawsze odgrywają tu rolę znaczeniotwórcząa

We wcześniejszych, „śródmiejskich” utworach znikanie miejskich krajobrazów bywało kojarzone z powidokami ${ }^{10}$ wojennych ruin, jak np. rozbiórki starych, niszczejących kamienic. Motyw ten powraca w kontekście roślinnym

6 Lotnisko sportowe Aeroklubu Warszawskiego, o którym wspomina Białoszewski, faktycznie istniało od 1946 roku w miejscu, w którym przed wojną planowano budowę lotniska pasażerskiego. Działało do roku 1976, gdy teren przeznaczono pod budowę osiedla mieszkaniowego Gocław.

7 Autoetnograficzny charakter zapisków Chamowa analizowałam szczegółowo w tekście Międzymiejsce. Antropologia codzienności - antropologia miasta - antropologia literatury. Analiza relacji na przykładzie „Chamowa" Mirona Białoszewskiego, "Teksty Drugie” $2014 \mathrm{nr} 6$.

8 Na narastający w późnej twórczości pisarza wątek śmierci zwraca uwagę np. J. Grądziel-Wójcik "Święte życie" na Lizbońskiej...

9 M. Czermińska Miejsce autobiograficzne. Propozycja w ramach geopoetyki, „Teksty Drugie” 2011 nr 5; M. Zielińska Wieczne miasto na ruchomych piaskach, w: Warszawa-dziwne miasto, Wydawnictwo IBL PAN, Warszawa 1995. Zob. także: A. Karpowicz Rytm prozy - rytm życia. Miron Białoszewski "ciało w ciało" z miastem, w: Przestrzenie geo(bio)graficzne w literaturze, red. E. Konończuk, E. Sidoruk, Wydawnictwo UwB, Białystok 2015; Mironizm: praktyki, kontekstyi gatunki miejskie, „Białostockie Studia Literaturoznawcze” 2014 nr 5.

Powidokowy sposób literackiego widzenia przestrzeni w twórczości Białoszewskiego uzasadniałam w tekście „Krajobraz jako oko”. Powidoki Mirona Białoszewskiego, w: Więcej niż obraz, red. E. Wilk, A. Nacher, M. Zdrodowska, E. Twardoch, M. Gulik, Wydawnictwo Naukowe Katedra, Gdańsk 2015. 
w rozmowie podczas spaceru po Porcie Praskim - terenie, którego znaczną część zajmuje do dziś chroniony obszar lasu łęgowego:

Teraz już dużo drzew. Wierzby. Pękami. Po dziesięć, po piętnaście z jednego miejsca. Wysokie.

[...]

- I to mają wyrżnąć. Zmienić. Ulepszyć. Mają zrobić bulwar. Po co tu bulwar? Co tu ulepszać? No powiedz, co tu jeszcze można zrobić? Tylko gnoju nawieźć, żeby jeszcze lepiej zarosło.

- Tylko. To ci, co rozbierają stare kamienice. Zawsze ludzkość była taka?

- Zawsze. ${ }^{11}$

W Chamowie pisarz łączy zagładę z zanikaniem krajobrazów roślinnych, tłumacząc się jednocześnie ze swojej pasji zrywania okolicznego zielska: „Tuż przed padaniem zjechałem windą do sklepu. Przez łączkę ściętych badyli. Nie wszystkie ścięte. Leżą świeżo wyrwane, nie wiem, czy w trakcie, czy to już koniec szału. Komu na tym zależy. Jakie wielkie, mokrozielone łopuchy, szczawie, chrzany. Czy i to zetną? Rzuciłem się, żeby trochę ich narwać. Skoro i tak grozi im zagłada” (C, 155); „Więc póki są, to przynoszę. Szkoda mi rwać, ale nie mogę się nieraz powstrzymać $(C, 168)$.

Prawobrzeżna Warszawa widziana przez Białoszewskiego wydaje się więc terenem zielonym, dzikim, opanowanym przez roślinność, ale tuż przed jej wykarczowaniem. Mnóstwo tu łąk pełnych chwastów, które pisarz zrywa zarówno przy własnym bloku, jak i na obrzeżach miasta, zarośli, „gęściochy" (C, 11), przez którą się przedziera, jest tu „dżungla nad dziką Wisłą" (C, 385), są też podmiejskie lasy eksplorowane przez poetę i „stepy" (C, 385 i in.) Gocławia czy krzaki Grochowa. Co ciekawe, z tą literacką wizją Białoszewskiego, którą rozumieć można zarówno biograficznie, jak i metaforycznie, doskonale współgra dokumentacja historii dzielnicy, uzmysławiająca też procesy, w których cyklicznie obrastała ona „zielskami” obficie zbieranymi przez pisarza i była z nich ogołacana:

Między domem a Trasą Łazienkowską ni to skwer, ni to łączka. Le powiedział

- Tu była sadzawka, ale już ją zakopali.

Został rząd topól, idących ukosem przez łączkę. Agnieszka wpadła na odkrycie

11 M. Białoszewski Port Praski, w: Rozkurz, PIW, Warszawa 1998, s. 58. 
- To po tych wsiach

i ja sobie przypomniałem, że ileś lat temu zwiedzałem przyszłą Trasę $€$ i na jej przedłużeniu wyszedłem na jakiś folwark, łąkę. Pasły się krowy, jedna obróciła za mną głowę i długo mi się przyglądała. I to było chyba to moje przyszłe miejsce. $(\mathrm{C}, 6)$

Istotnie, jeszcze w 1967 roku podpis pod zdjęciem przedstawiającym krowę przeprowadzaną przez grochowski odcinek alei Waszyngtona głosił: „W stolicy, na podmiejskich terenach rolniczych, hoduje się zwierzęta gospodarskie, m.in. ponad 3 tys. koni, 170 kóz i około 1000 owiec"12, a duże gospodarstwo rolne Zajdlów działało na Witolinie jeszcze na początku lat 8o. XX wieku, choć stopniowo ograniczano je terytorialnie. Na prywatnych zdjęciach mieszkańców, gromadzonych przez Witrynę Grochów ${ }^{13}$, uchwycono łany zboża, rozsiane wśród nich kwiaty, ale i tradycyjną, podmiejską i zagrodową zabudowę z architekturą jednorodzinną, przydomowymi ogródkami, obrośniętą kwitnącymi krzewami i drzewami. W oficjalnych narracjach krajobrazy te i charakterystyczna dla nich zabudowa przedstawiane były wtedy jako niechciany przeżytek poprzedniej, archaicznej epoki i zastępowane nowoczesnymi blokami z lepszą infrastrukturą i oferującymi bardziej cywilizowane, wygodne warunki życia, burzono je więc pod nową architekturę osiedlową. "Rozbudowująca się stolica zaczyna w niespotykanym dotychczas stopniu «pożerać» stare czynszówki i przedwojenne bieda-budownictwo. Tylko w tym roku - by dać miejsce na wznoszenie nowych osiedli - rozebranych będzie ponad 700 domów i domków. Ich mieszkańcy otrzymają lokale w nowym budownictwie" - czytamy pod fotografią osiedla Przyczółek Grochowski, wykonaną przez Tadeusza Zagoździńskiego w marcu 1973 roku ${ }^{14}$. Dowodzi tego również cykl fotograficzny Ginace przedmieścia Leonarda Sempolińskiego z lat 1977-1978 ${ }^{15}$, zaskakująco

Fot. Edmund Uchymiak, źródło: PAP, sygn. 19670401_007.

Zob. internetowe archiwum Witryny Grochów: http://witrynagrochow.pl, https://www.facebook.com/pg/Witryna-Groch\%C3\%B3W-1517770581771214/photos/?ref=page_internal.

Źródło: PAP, sygn. 274067/11.

Zob. M. Wróblewska Portret miasta - praktyka dokumentu Leonarda Sempolińskiego, w: Polska fotografia dokumentalna na skrzyżowaniu dyskursów. Materiały z sesji zorganizowanej w dniu 2 IV 2005 z okazji wystawy Leonarda Sempolińskiego, red. M. Jurkiewicz, Zachęta Narodowa Galeria Sztuki, Warszawa 2006. Fotografie Sempolińskiego można obejrzeć w wirtualnej galerii: http://organizacja.home.pl/projekty/sempolinski/archiwum.php. 
dobrze korespondujący z literackimi spostrzeżeniami i ich przetworzeniami w prozie Białoszewskiego, powodowany - zbieżną z treścią zapisów Chamowa - chęcią uchwycenia tych krajobrazów, które za chwilę miały zniknąć. Co istotne w kontekście twórczości autora Pamiętnika z powstania warszawskiego, cykl Sempolińskiego był poniekąd kontynuacją wcześniejszych prac fotografa, przedstawiających Warszawę tużpowojenną, zrujnowaną i zagospodarowywaną właśnie na nowo, przy czym obiektyw skierowany został właśnie na to, co za chwilę zniknie, zamiast na to, co się budowało. Zdjęcia Pragi Południe z lat 70. przedstawiają drewnianą i obracającą się powoli w niebyt mazowiecką, ogródkowo-drewnianą architekturę, tę samą, w której rozregulowywanym właśnie porządku przestrzennym, Białoszewski wielokrotnie się gubił i błądził wśród „zielsk”.

W Chamowie nie bez znaczenia pozostają różnice między roślinnością starej i nowej, „dobudowywanej" Warszawy, np. gdy autor-narrator porównuje drzewa rosnące na Pradze Południe z topolą sokorą z placu Dąbrowskiego, bohaterką licznych wierszy i opowiadań we wcześniejszym okresie jego twórczości:

Dojechałem do rozjazdu Korkowej, Ostrobramskiej, Grochowskiej i Marsa i przesiadłem się na autobus do Kawęczyna, Chełmżyńska, odwidlająca się od Marsa, cała zarośnięta różnościami, a głównie żółtymi kępkami guzikowców. Stoją przy niej zagrody. Coraz topola. Tak zwana sokora. Taka jak u mnie na placu Dąbrowskiego. Bo te na Chamowie to nie sokory. $(\mathrm{C}, 85-86)$

Nowe topole, nie-sokory, to gatunek masowo sadzony w okresie dynamicznej budowy warszawskich (i nie tylko) osiedli mieszkaniowych w czasach PRL, ponieważ ich krótki czas wzrostu i małe wymagania ułatwiały obsadzenie nimi poboczy nowych arterii komunikacyjnych i zakładanie terenów zielonych na osiedlach powstających w miejscu wykarczowanych łączek lub sadów i ogrodów niepielęgnowanych już przez byłych właścicieli. Sokora rosnąca na placu Dąbrowskiego, przywoływana tu przez poetę, to inny gatunek, topola czarna (Populus nigra), nazywana też nadwiślańską i wyróżniająca się ciemnym kolorem kory, rosnąca również dziko. Różne gatunki topól, czujnie odnotowywane przez pisarza, odwołują do różnych czasów ich sadzenia w Warszawie i do różnej genezy ich obecności w mieście. Warstwy szaty roślinnej, wręcz nadobecnej w Chamowie, są więc po części jednymi z „warstw 
czasu, warstw miasta”16, z których Białoszewski konstruuje swoją opowieść. Bujna roślinność, pozostawiona samej sobie i oczekująca na wycinkę, stanowiła wciąż ślad dawnych funkcji i wiejsko-podmiejskich sposobów użytkowania tej części prawobrzeżnej Warszawy. Również Port Praski w momencie, w którym uchwycił go Białoszewski, nie był już używany i od około 1970 roku służył tylko jako przechowalnia starego dworca wodnego, wykorzystanego $\mathrm{w}$ funkcji niszczejącej przestrzeni magazynowej. Zieleń rozrastała się więc tu swobodnie, a tereny portowe miały dopiero być zagospodarowywane, co w Porcie Praskim, jak widzieliśmy, komentują bez entuzjazmu spacerujący po nim Le. i Białoszewski. Zarówno w tym opowiadaniu, jak i w Chamowie powraca też nazywanie tych miejsc uroczyskami lub świętymi gajami, co odsyła do kolejnego wymiaru czasu: z jednej strony uroczyska związane są z czasem legendarnym i mitologicznym (po który Białoszewski sięga równie często, przywołując historię objawień siekierkowskich czy wyobrażając sobie, że jedna ze scen biblijnych rozegrała się na Siekierkach), a z drugiej odsyłają do najbardziej pierwotnych, rodowo-plemiennych, podziałów terytorialnych puszcz i leśnych ostępów.

Rośliny wprowadzają w Chamowie czasowość alternatywną wobec czasu linearnego, upływającego, jak pamiętamy, nieubłagalnie i stanowiącego ramę konceptualną utworu oraz szkielet konstrukcyjny dziennika-opowieści pisanego przez rok po przeprowadzce. To czas, który przyrasta, narasta i obrasta dane miejsce, czas zapisany w jego warstwach geologicznych, rozciągający się w głąb, a nie wzdłuż. Białoszewski tak też używa historii terenów Pragi Południe, czyniąc z niej element opowieści o czasie i zmianach, o nawarstwianiu się jego ciągów w przestrzeni, np. wtedy, gdy gęste zarośla i „kumosy”"17 prowadzą poetę do pomnika upamiętniającego bitwę ze Szwedami i wprost w głąb XVII wieku, albo wtedy, gdy w chaszczach Grochowa schodzi do czasów powstania listopadowego, związanych z lokalną historią miejsca. Dzieje się tak również, gdy na widok sielskiej ulicy Kawczej na Grochowie: „między polami, łąkami, pustkami”, „w kocich łbach, domowo-chałupowej, z parkanami", nakłada jej przedwojenne wspomnienie jako „raczej wytwornej” (C, 88), a na eleganckiej Saskiej Kępie czy w Parku Skaryszewskim przywołuje ich łąkowo-pastwiskowo-ludyczny charakter sprzed i z międzywojennej modernizacji, ale też w momencie, gdy patrząc na nowoczesną Trasę Łazienkowską,

16 K. Kuzko-Zwierz Warstwy czasu, warstwy miasta. Białoszewskiego latanie na Grochów, w: „Tętno pod tynkiem"...

17 M. Białoszewski zo lipca w nocy, w: Wiersze. Wybór, PIW, Warszawa 2003, s. 193. 
jak widzieliśmy, przywołuje pasące się tu kiedyś krowy ${ }^{\mathbf{1 8}}$. Roślinne „obrastanie” (C, 114) miejsca życiem wyraża więc geologiczną, warstwową, „białoszewską" koncepcją czasu, którą najlepiej chyba materializowałby czterowymiarowy przekrój słojów drzewa.

\section{Czwarta natura}

Czwarta natura - tak mówi się we współczesnej teorii nowych ekosystemów o wszystkich tych łąkach i nieużytkach, na których poeta szukał materiału do swoich bukietów i wypowiedzi artystycznych: terenach porolniczych, uprawnych czy miejscach po zamkniętym lotnisku albo śmietniskach między lasem a polem żyta:

Zawiozłem raniutko żółte kwiaty, do tego trochę białych, niebieskich. Dziki bukiet, pachnie miodem z Kawęczyna. Wysiadłem z autobusu na ostatnim przystanku, bez planu. Zajrzałem za barak z parkanem; ścieżka, idą z teczkami, trawa, wyka, miodowniki, żyto z chabrami. Idę, górki, dołki, krzaki, tu śmiecie, tu pachnie, tu sadzawka, łowią ryby, tu wyrzucone wałki od otomany. Przepięknie. (C, 66)

Obraz śmieci znalezionych w leśnych zaroślach - motyw dobrze znany z wcześniejszej twórczości pisarza - w Chamowie wybrzmiewa jako jedna z „brzydotek”, które poetę zawsze „cieszą" i „podniecają"19, chociaż tu również jest on kojarzony zagładowo z krematoriami za sprawą upału i unoszącego się nad śmietniskiem smrodu zgnilizny:

Wreszcie jeżyny, trzciny, osty, drzewa, krzaki i całe olbrzymie zagajniki na wysokość człowieka jakichś zielsk, które okazały się polską mimozą; [...] Wszedłem w las. Nie chciało mi się wierzyć, że zaraz będzie śmietnisko Warszawy. Góra z piachu. Nagła. W gęstych drzewach. Wdrapałem się na nią. Ale zobaczyłem las i nieprzebyte tłumy polskiej mimozy.

18 Szczegółowo o warstwach historycznych wydobywanych przez Białoszewskiego zob. K. Kuzko-Zwierz Warstwy czasu, warstwy miasta...

"brzydotki cieszą/brzydotki podniecają/na tych samych prawach/co piękności" - tak w wierszu z cyklu Trynkowanie mrówkowca z 1978 roku Białoszewski podsumował swój zachwyt nowymi okolicami, w których zamieszkał w latach 70. M. Białoszewski Wysnucie z zaskoku, w: Wiersze. Wybór, s. 210. 
Dalej coś majaczyło. Może to grzbiety śmieciowe. [...] Znalazłem przejście. Tak. Porzucone kapcie. Setki pantofli. Termosów. Blach. Papierów. [...] Tam dalej całe pokłady śmieci.

To już zjawisko geologiczne. Tu na gorącym uczynku przyłapuje się ludzkość zagrożoną odpadkami, opakowaniami. (C, 87)

Pograniczne formy i asamblażowa mieszanina natury i kultury, odpowiadające też rekonstruowanej przeze mnie wcześniej pograniczności przestrzeni i nieostrości jej kategoryzacji, przybierają tu postać narastających w czasie warstw geologicznych. Tak ujęta budowa Ziemi wskazuje na asamblażowy właśnie - w równym stopniu naturalny, jak i kulturowy charakter procesów, które ją przeobrażają, i powodują jej wertykalne przyrastanie w czasie. Koresponduje z nimi charakter roślinności fascynującej Białoszewskiego w okresie „lizbońskim”: wyrastające na obszarach porzuconych przez człowieka rośliny synantropijne ${ }^{20}$, zarastające ugory i nieużytki, przejmujące je po ludziach w procesie naturalnej sukcesji, biorące we władanie śmietniska, będące paradoksalną formą nie-naturalną (nienależącą do pierwszej natury), a jednocześnie naturalną, bo w przeciwieństwie do drugiej i trzeciej, niezasianą i niepielęgnowaną intencjonalnie w ramach "porządnickiego" (C, 85) świata kultury ${ }^{21}$.

Ze względu na ten płynny i nieostry charakter miejskiej roślinności, trudnej do zakwalifikowania, ponieważ podważającej utarte podziały na naturę i kulturę, jeden z badaczy nurtu nowej miejskiej ekologii proponuje wręcz zastosowanie teorii queer, stworzenie queer ecology, aby używać jej „do ponownej refleksji nad istniejącymi kategoriami”, mówiąc też w tym wypadku o „asamblażu ekologicznym", a więc używając języka zaczerpniętego z historii sztuki²2. Wszystkie wymienione tu terytoria badawcze, jak dobrze już wiemy z wielu

Zob. B. Gawryszewska, M. Łebkowski Estetyka nieużytku we współczesnej architekturze krajobrazu miasta, "Sztuka i Filozofia” 2016, nr 49.i J. Janecki Człowiek a roślinność synantropijna miasta na przykładzie Warszawy, Wydawnictwo SGGW-AR, Warszawa 1983; E. Trzaskowska Zastosowanie roślinności synantropijnej w kształtowaniu terenów zieleni miast - nowe nurty w projektowaniu, „Nauka. Przyroda. Technologie” 2012 t. 6, z. 2.

21 W tym podziale pierwsza natura to roślinność naturalna, ceniona najwyżej w klasycznej ochronie środowiska, a drugą naturą nazywa się roślinność środowisk leśno-rolnych, trzecią zaś tę, która rośnie na zagospodarowanych terenach zielonych w mieście, np. w parkach i ogrodach. Zob. B. Gawryszewska, M. Łebkowski Estetyka nieużytku... 
opracowań, mają wiele wspólnego z estetyką Białoszewskiego, podobnie jak nieużytkowość i spontaniczność form życia charakteryzujące ugory.

„Rośliny rosnące spontanicznie”23, które nie mogą żyć w schludnych i pielęgnowanych parkach czy ogrodach, służących wprowadzeniu uporządkowanej przyrody w przestrzeń miasta, świetnie przystosowują się do życia gdziekolwiek: uzależnione od ludzkiej działalności czy raczej jej zaniechań, radzą sobie bez udziału człowieka. Narratora najbardziej cieszą znaleziska-rośliny rosnące samorzutnie, pospolite, często też rozprzestrzeniające się prawie wszędzie, zagnieżdżające się w miejscach już lub jeszcze niezagospodarowanych, dostosowujące się do różnych, nawet trudnych warunków, mało wymagające, będące uciążliwymi chwastami, jak nieuprawny koper, dziki chrzan, niedający się łatwo okiełznać w uporządkowanych ogrodach, czy też polska mimoza, często przywoływana w Chamowie, czyli nawłoć pospolita, rosnąca na ugorach, ale i w wiejskich ogródkach czy rowach i rozrastająca się bujnie w sposób trudny do wyplenienia. Rośliny te rosną więc na terenach o niejasnej przynależności i nieostrym statusie, a tak też w Chamowie przedstawiona jest Praga Południe: pół-wieś, pół-miasteczko, już nie przedmieście, ale jeszcze nie miasto. Co znamienne, dużo rzadziej i mniej szczegółowo opisuje się tu pobliski Park Skaryszewski, chociaż jest on doceniany i dostrzegany w Chamowie. W mikroskali perspektywę tę widać podczas - coraz rzadszych i coraz bardziej melancholijnych - samotnych pobytów w dawnym mieszkaniu na placu Dąbrowskiego, w którym wciąż mieszka partner poety: „Podlałem amarylis, bezkwiatowy, bo kwitł dwa razy, teraz same liście. Ładne. Ciut podeschłe końce u dwóch. Na boku doniczki zielsko samorodne. Ładne było, zbrzydło, zdycha" (C, 161). Białoszewski wyławia w otoczeniu niepotrzebne „zielska” rosnące bez kontroli, obrastające śmietniki i zagnieżdżające się poza nadzorem w mieście i w doniczkach,jakby przypadkiem, przy okazji i bezcelowo, na terenach niepielęgnowanych i poniechanych. Perspektywa ta jest związana z właściwym poecie przewartościowaniem kategorii estetycznych, o czym wiele już napisano od czasu wydania Obrotów rzeczy.

Oryginalnie rozumiana florystyka, sztuka układania bukietów z „zielsk” i kwiatów, wydaje się - oprócz „sztuki chodzenia” czy jeżdżenia po mieście ${ }^{\mathbf{2 4}}$ i magnetofonowej, polegającej na czytaniu i nagrywaniu własnej prozy

23 P. Del Tredici The Flora of the Future, „Places Journal” April 2014, https://doi.org/10.22269/140417 (31.01.2018).

24 Szerzej pisałam o tym w tekście Topo-Grafie (w) ruchu. Sztuka chodzenia Mirona Białoszewskiego, "Konteksty. Polska Sztuka Ludowa” 2015 nr 4. 
i wierszy - jedną z podstawowych praktyk artystycznych Białoszewskiego w ostatnim okresie twórczości ${ }^{25}$. Bukiety, formowane z kupionych czy zebranych, żywych lub ususzonych kwiatów, stawały się główną atrakcją „wtorków”, spotkań artystyczno-towarzyskich w nowym mieszkaniu poety, były starannie i z rozmysłem komponowane, prezentowane gościom, komentowane przez nich i podziwiane, a następnie stawały się tematem literackim. Głos Białoszewskiego nagrany na magnetofon Stańczakowej brzmi tu wyjątkowo plastycznie, słychać zaangażowanie i podekscytowanie układaniem „zielsk”, naśladowanie przez niego wypowiedzi gości polega na szczególnym podkreślaniu ich podziwu i zachwytu bukietem:

Więc w tym zielonym dzbanie były gladiolusy, trochę przywiędły/w różnych kolorach, czerwieni, fioletu, takie jak indyki, nad nimi ogromna kumosa, taka jak choinka, z listkami, z krupkami/pamiętasz takie?/Tak, białe/Biało-zielone/A tak/Więc teraz te łopuchy szmaragdowe z tym razem/u góry choinka, u dołu wielka ćma/dwuskrzydłowa, zielona, $\mathrm{z}$ indorami/ a tu, po prawej stronie wysokie zielska zasuszone. Do tego dołożę dzisiejszy koper dziki. Wyobraź sobie łodygi jak do spadochronów. To razem jak ze starego podręcznika zielarskiego. W koper wetknąłem trzy zasuszone polskie mimozy. Znów stara szkoła. Po tej hrabinie, co prawdziwe szmaragdy podbijała zieloną bibułką. Przyszedł Tadzio/ O, koper polny/ Spróbował/Ma smak mydła. Przyszli inni goście/ wyjąłem ognichę, ileś pawich piór z żółtymi kwiatuszkami na łodydze/Widzicie, to takie pióropusze, niosą z dwóch tron/po środku papież, w lektyce/ Wszystko się kiwa w tłoku/Znacie z telewizji/Goście spytali: czy pan sam?/Właśnie, czy ty sam, czy ci ktoś układa te kwiaty?26

Podzielam tu zdanie Jacka Kopcińskiego upatrującego w nagraniach Białoszewskiego i samych seansach magnetofonowych pełnoprawnej formy sztuki. Zob. J. Kopciński Człowiek transu: magnetofonowe sesje Mirona Białoszewskiego, "Teksty Drugie” 2011 nr 4. Jadwiga Stańczakowa rozróżnia kilka gatunków tej sztuki performance autora Chamowa, w tym wiersze nagrywane po nocnym pisaniu i "lataniu po uroczyskach", które nazywa "Misterium Sztuki" (Dziennik we dwoje, oprac. J. Borowiec, Warstwy, Wrocław 2015, s. 90). Szerzej uzasadniam ten pogląd w tekstach Wibracje Mitsuku. Archiwum głosu Mirona Białoszewskiego , "Konteksty. Polska Sztuka Ludowa" 2018 (w druku) oraz L'archive de la voix. Une nouvelle dimension du texte littéraire de Miron Białoszewski, "Acta Fabula" 2018 (w druku). 
Według słów Stańczakowej, bukiety zmieniały się w szczególny rodzaj sztuki: „kwiato-krzako-plastykę"27, która - na co zwraca uwagę autorka Dziennika we dwoje - jest jednocześnie „kwiato-zielskową tradycją wtorków”"28 związaną nierozerwalnie właśnie z „lizbońskim” okresem życia i twórczości Białoszewskiego, przygotowującego wtedy budzące podziw instalacje z „zielsk” i domową scenę dla swoich pół-towarzyskich i pół-artystycznych, nieformalnych wieczorków. Kompozycje te służyły również licznym kontemplacjom estetycznym, wywoływaniu halucynacyjnych efektów wizualnych:

Przyniesione dwa dni temu gałęzie wierzbowe, podobne do palmowych, usychają, podkręcają się, a to psuje ich rytm graficzny, a i plamistość. [...] Więc palmowe gałęzie w dzbanie usychają, ale te, co na ścianach, wiszą. Bo zawiesiłem takie pióropusze na patykach. Ognichy. Te pobrązowiałe wyglądają ośmiornicowato. Są między ścianą a sufitem. Nie wiadomo, gdzie ich kosmate nogi, a gdzie cienie tych nóg. Chwilami wydaje się, że już zaczynają latać jak pająki, jak dym. Bylice ogromne. Wielkości choinki. Kolor fioletowoszary. Po przyschnięciu listków i krupek gałęzie zachodzą na swoje delikatne cienie, a te na świątki. Jak koronki, bardzo skomplikowane. Raz to podobieństwo wydało mi się oczywiste, i tak pozostało $(C, 127)$.

Wokół domowych bukietów odprawiane były samotne mikroobrzędy z chodzeniem, paleniem świec i kadzideł, wspomagających wprowadzanie się w transy opisywane w Chamowie. Na wykorzystanie bukietów ze znalezionych przypadkowo, choć dobieranych z rozmysłem „zielsk", w funkcji półsakralnej, półmedytacyjnej zwracała uwagę również Krystyna Rodowska, wspominając spotkania z Białoszewskim z tamtego okresu w Domu Pracy Twórczej w Oborach, a zwłaszcza sposób, w jaki zagospodarował swój pokój:

Z tych nocnych eskapad znosił przeróżne trofea. Zapukałam kiedyś do jego narożnego pokoju na parterze i oniemiałam: z lampy pod sufitem i z obramowania lustra nad umywalką zwieszały się całe gałęzie z grzywą liści i fioletowo-czarnych owocków, prawdopodobnie „wilczej jagody" albo kruszyny, co w połączeniu z czarnym papierem, naklejonym na okienne szyby - tak by odgrodzić się od dziennego światła i tego, co

27 J. Stańczakowa Dziennik we dwoje..., s. 37.

28 Tamże, s. 79. 
działo się na zewnątrz - sprawiało wrażenie jakiegoś przedziwnego sanktuarium, czy kaplicy, służącej medytacjom. ${ }^{29}$

Do tych skojarzeń Rodowskiej dodałabym również obrzędy funeralne, związane zarówno z paleniem świec, sakralnością, jak i kwiatami. Motyw śmierci - ważny w „lizbońskim” okresie twórczości - w Chamowie wybrzmiewa szczególnie wyraźnie, gdy narrator utożsamia swoją kondycję i sytuację egzystencjalną z krajobrazem miejskim: „Kusi mnie krótkie przelecenie przez wertepy Grochowa. Ulubiłem go sobie. Podobno grozi mu zagłada. Mnie też. Więc nie ma się co przejmować. Zobaczymy się póki co" (C, s. 278). Jak pamiętamy, podobną motywację zdradzał, tłumacząc się z rwania „zielsk".

Bukiety, podobnie jak kompozycje z chabrów, śmieci i łanów zboża, obserwowane na nieużytkach, charakteryzuje właściwa pisarzowi estetyka asamblażu: gałęzie krzaków mieszają się tu z kwiatami suszonymi, żywymi, ciętymi, ogrodowymi czy polnymi chwastami, pozornie nie przystają one do siebie, każdy należy do innej konwencji i stylistyki, ale powstaje z nich spójna, zachwycająca gości instalacja artystyczna. Estetyka zbieractwa rekonfiguruje hierarchię wartości na równi z ekonomią nieużytków. Zbieractwo przedmiotów czy roślin - definiowane przez Tomasza Rakowskiego jako „relacja pamięci na poziomie czynności w środowisku, nawracających ruchów i nowego orientowania się w otoczeniu, tak aby nagle dostrzeżone zostawały jego partie"30 - charakteryzuje zaś wymykanie się schematom i strukturom działania, które obowiązują w danej społeczności. Otwierają je na niecodzienne użycia i proponują zaskakujące zastosowania dla rzeczy i roślin.

Rekonstruowany tu model estetyczny zawiera w sobie przede wszystkim rekonfigurację hierarchii wartościowania przestrzeni miejskiej, a także alternatywny, lokalny sposób myślenia o jego ekosystemie. Jak dowodzą współcześni ekologowie i architekci krajobrazu, to w tradycyjnej ochronie środowiska miasto uznaje się za zaburzone, a rośliny rosnące spontanicznie, odległe od idei pierwszej natury, traktowane były jako bezwartościowe. Teoria

K. Rodowska Dzikie atramenty, "Wszystko Co Najważniejsze" 14 stycznia 2017, https://wszystkoconajwazniejsze.pl/krystyna-rodowska-dzikie-atramenty-albo-szkola-obmowy-mironabialoszewskiego/ (20.01.2018). 
nowych ekosystemów zmienia ten sposób myślenia, a przecież to właśnie dla Białoszewskiego miasto było zawsze natu ra l ny m środowiskiem i,jak głosi anegdota, na propozycję wyjazdu w Tatry, żeby zobaczyć góry, odpowiadał, że nie musi tego robić, ponieważ ma je w mieście ${ }^{31}$.

Krystyna Rodowska, pisząc o aranżacjach z „zielsk” w pokoju Białoszewskiego w Oborach, zwraca również uwagę na operację językową, jakiej dokonuje poeta, nie nazywając roślin ich potocznym określeniem „wilcze jagody” czy „kruszyny”, lecz peryfrazą „dzikie atramenty”, tworząc napięcie czy zderzenie między tym, co kulturowe, a tym, co dzikie: „sferą niezdobytej przez język rzeczywistości”, „dzikością niewyrażalnego"32.

Niewątpliwie kwestie niewyrażalności stawały się w okresie „lizbońskim" szczególnie ważne, chociażby dlatego, że był on nierozerwalnie związany z najintensywniejszymi w życiu Białoszewskiego kontaktami z niewidomą Jadwigą Stańczakową, także za sprawą seansów magnetofonowych. Przyjaciółka operuje tylko zmysłami węchu i dotyku, wielokrotnie w swoim dzienniku odnotowuje zapach lip, bzów, czasem urywa listek, żeby mieć „zieleń w ręku"33 a Białoszewski zwraca uwagę na jej sensoryczne usytuowanie w świecie: „Miron podsuwał mi do dotykania i wąchania gałązki kwiatu kwitnącej wiśni i topolowe bródki. Wszędzie kwitną czeremchy" ${ }^{34}$, organizuje nieustannie sytuacje, w których przyjaciółka może z nim współodczuwać i dzielić doświadczenie, a także wybiera dla niej kwiaty (które bardzo często i hojnie, wraz z owocami i trudno dostępnymi lub drogimi produktami spożywczymi, przynosi jej na Hożą) głównie ze względu na ich zapach, natomiast kwiaty dla innych znajomych, dobierane są kolorystycznie:

8 maja, czwartek

Mironowy dzwonek

- O, to dla ciebie. Pachnie! - Podaje mi pęk narcyzów. Okazuje się, że trzydzieści. ${ }^{35}$

Anegdota opowiedziana przez Tadeusza Sobolewskiego podczas spotkania "Miron Białoszewski - warszawski poeta do szpiku kości", 27 listopada 2014 roku, Dom Spotkań z Historią w Warszawie. Zob. zapis fragmentów nagrania: http://topo-grafie.uw.edu.pl/miron/topobiografia/.

K. Rodowska Dzikie atramenty...

Tamże, s. 233-234.

Tamże, s. 35. 
Wtedy też, w latach 70. XX wieku, rozwija się dynamicznie psychotroniczna działalność Lecha Emfazego Stefańskiego ${ }^{36}$, w którą angażowana jest zarówno ucząca się „widzenia skórnego" ${ }^{37}$, polegającego na wyczuwaniu kolorów, niewidoma Jadwiga, jak i autor Szumów, zlepów, ciągów. Choć zapisy Tajnego dziennika dowodzą również jego dystansu do parapsychologicznych praktyk przyjaciela, w jednej z notatek Stańczakowa odnotowuje jednak: „Lech Emfazy opowiadał ciekawostki psychotroniczne o roślinach, które popierane myślami różnych ludzi z różnych stron rosły dużo lepiej niż inne rośliny, stojące obok w doniczkach. Mirona to zainteresowało"38.

Zainteresowanie roślinami wpisuje się więc wtedy w poszukiwania alternatywnych form komunikacji. Z jednej strony bujna dzikość „zielsk” wspomaga słowotwórczy żywioł, gdy trzeba - a Białoszewski czyni to często, na co wskazują zarówno zapiski Dziennika we dwoje, jak i fakt, że Stańczakowa była wierną towarzyszką wypraw po „zielska”, a także słuchaczką opowieści o bukietach i zaroślach, choćby podczas nagrywania zapisków Chamowa na magnetofon - przetransponować to, co naoczne, i opowiedzieć Jadwidze o wizualnym doświadczeniu roślinnym, a z drugiej, gdy bujną mnogość "gęściochy" Białoszewski próbuje ująć w języku.

Chwasty, po które jeździ Białoszewski, są przez niego również językowo egzotyzowane, nie tylko wtedy, gdy wprost przyrównuje tereny, na których rosną, do stepów czy dżungli:

poniedziałek. Pojechałem o szóstej rano na Zerzeń. Wszędzie ładnie. Wracałem przez Gocławek. Wysiadłem zaraz za wylotem Traktu Lubelskiego, skręciłem w te łąki i zagajniki, do których szliśmy z Tadziem w maju nie mogliśmy się dostać. Trafiłem prosto na mostek, dalej droga przez sam środek raju. Coraz rów. Rów odchodzi od rowu. Rosną olchy, trzciny, piętrowe szczawie, pokrzywy, liany, plątaniny, kwiaty, wieże z kaszą na parasolach. Bujność nieprzebyta, nieodwiedzana. Jak zaczyna się jakieś

Stowarzyszenie Radiestetów w Warszawie powstało formalnie w czerwcu 1976 roku, a w grupie psychotroników, radiestetów i różdżkarzy był właśnie Lech Emfazy Stefański, działający w tej dziedzinie już wcześniej wraz z innym znajomym Białoszewskiego, Bogusławem Choińskim. Stefański był później założycielem i prezesem Polskiego Stowarzyszenia Psychotroników.

37 Zob. rozdział Widzenie skórne w: L.E. Stefański, M. Komar Od magii do psychotroniki, Wiedza Powszechna, Warszawa 1980. 
rozbuchania: na przykład kasza w parasolach z rudą kaszą piętrową, to już ciągnie się ich całe pole po obydwu stronach. Jak pokrzywy za trzcinami, to pokrzywy, pokrzywy, trzciny, trzciny, a wszystko to raz między olszynami, raz w olszynach. Z lianami. Bronią wstępu. (C, 112-113)

Rośliny pospolite przedstawia się jako dzikie, egzotyczne gatunki, a wycieczka nieopodal domu staje się wyprawą do innego krajus również wtedy, gdy Białoszewski nagle zostawia Stańczakową samą z zakupami, by spontanicznie zbierać „baobaby” czy „baowachlarze”"40. Same nazwy roślin brzmią egzotycznie i tajemniczo: czasem ze względu na regionalne, ludowe określenia („bodiaki”, inaczej „osty”), którymi posługuje się pisarz, a innym razem ze względu na obce, łacińskie ich brzmienie ("gladiolusy” zamiast „mieczyki”). Środowisko roślinne przepełniają zarówno dzikie „szczawie”, jak i „kobylaki” („szczaw koński” lub „szczaw kędzierzawy”), „kumosy” stające się czasem "choinkami”, sugestywne „ognichy” („ognicha polna”, inaczej „gorczyca polna”), swojskie „byczki” i „kopry”, „łopuchy” i „lebiody”, ,olchy”, , pokrzywy”, "trzciny" "kasze, ale i tajemnicze "guzikowce" - ten krzew ozdobny z oryginalnym kwiatostanem jest rzadko spotykany w Polsce, Białoszewski prawdopodobnie nazywa tak wrotycz pospolity, jak można się domyślać ze względu na żółty kolor kwiatów, o jakim w tym kontekście zwykle pisze (nazwa ludowa: „złoty guzik”). Bioróżnorodności roślinnej rzeczywistości miejskiej odpowiada tu różnorodność językowa.

\section{*}

Żal za ginącymi nieużytkami, za łąkami, na których, jak przeczuwa pisarz, za chwilę nie będzie już można zbierać „zielsk”, to również właściwy estetyce Białoszewskiego gest opowiedzenia się po stronie „zagrożonej bylejakości” $(C, 68)$ i nieużyteczności: „Co pewien czas ktoś kładzie do pudła przy śmietniku całe chleby, buły. Biorę to wtedy i ciskam w nocy na pożarcie tutejszym [gołębiom - przyp. A.K.]. Nie jakimś koniecznym krowom. Jestem wtedy po stronie bezużytecznych"41. W „porządnickiej epoce" nierówne kocie łby stają się drogocennymi kamieniami (C, 85), a leżące odłogiem łąki dają poczucie

\footnotetext{
39 M. Czermińska Małe i wielkie podróże Mirona Białoszewskiego, w: Pisanie Białoszewskiego. Szkice, red. M. Głowiński, Z. Łapiński, Wydawnictwo IBL PAN, Warszawa 1993.

40 M. Białoszewski Rwanie piękności...

41 M. Białoszewski Mrowienie się, w: Małe i większe prozy, PIW, Warszawa 2000, s. 34.
} 
wymykania się spod jej nadzoru. Ten sposób bycia w przestrzeni miejskiej podkreślają też spontaniczne wyjazdy komunikacją miejską o dowolnej niemal porze dnia i nocy, tylko po to, by zbierać "zielska” i nagłe, powodowane czystą „zachcianką" lub „pół-zachcianką" (C, 216) albo potrzebą estetyczną, by dopełnić kompozycję barw i faktur, kupowanie naręczy kwiatów u ulicznych sprzedawczyń. Estetyka Chamowa okazuje się więc szczególnie bliska postulowanej dziś coraz częściej estetyce miejskich nieużytków ${ }^{42}$ avant la lettre, ale i prefiguracją ich ekonomii, realnie praktykowanej przez narratora powieści-dziennika.

Z klasyczną perspektywą ekologiczną miejskiego ekosystemu jako środowiska wynaturzonego koresponduje bowiem tradycjonalistyczna wizja planowania przestrzennego i tradycyjna ekonomia: pozostawianie nieużytków traktowane jest tu jako "marnotrawstwo przestrzeni” ${ }^{43}$. Natomiast ich zwolennicy, podobnie jak dzieje się w estetyce Białoszewskiego, przeciwstawiają „,rację ekonomiczną” $(C, 216)$ innej, „racji zachceniowej” (C, 79). Wartość estetyczną zyskuje zaś to, co nieuporządkowane, chaotyczne i samorodne, jak dzikie, nieuprawiane chwasty czy chabry zarastające śmieci lub inne tereny synantropijne, niepielęgnowane, uznawane tradycyjnie za synonimy zaniedbania i biedy ${ }^{44}$.

Jak piszą Beata Gawryszewska i Maciej Łebkowski, roślinność nieużytków od niedawna zaczyna być ceniona właśnie dlatego, że choć współistnieje z człowiekiem i jest z nim związana, to rozwija się spontanicznie i niezależnie od jego kontroli. Ich wartość nie polega na tym, że trwają niezmienione od wieków, lecz na tym, że potrafią funkcjonować w nowym i trudnym środowisku, przystosować się do niego i zmieniać. W świetle teorii ekosystemu okazuje się więc, że to właśnie nieużytki i obrastające je rośliny synantropijne, bezużyteczne, zaburzone i zbędne według dawnych sposobów myślenia o środowisku miejskim, oczyszczają skażoną glebę, absorbują dwutlenek węgla, redukują efekt miejskiej wyspy ciepła, a w ten sposób okazują się paradoksalnie - użyteczne. Co najważniejsze w odniesieniu do twórczości Białoszewskiego, uprawiającego w Chamowie taką właśnie, literacką estetykę nieużytków, jej zwolennicy, proponujący pozostawianie terenów obrastających roślinnością synantropijną, twierdzą, że dostarczają one miejsc, które

B. Gawryszewska, M. Łebkowski Estetyka nieużytku...

Tamże, s. 18. 
można - znów paradoksalnie - użytkować swobodnie, codziennie, ponieważ zwykle pozostają lokalnymi oazami zieleni, rozrastają się w pobliżu domów, są więc zawsze w zasięgu użytkowników. Badania prowadzone przez Gawryszewską i Łebkowskiego w Warszawie dowodzą, że mieszkańcy walczą dziś o zachowanie nieużytków i bronią ich przed zakładaniem na ich miejscu regularnych parków. Miejsca te można bowiem wykorzystywać oddolnie i nieformalnie, twórczo zagospodarowywać i strukturyzować dzięki niewymuszonym aktywnościom i praktykom podejmowanym tu przez mieszkańców.

Niekontrolowane procesy biologiczne, z jakimi mamy do czynienia na nieużytkach, postrzega się więc tutaj jako odpowiednik procesów społecznych, niezaplanowanych i spontanicznie rozwijających się poza odgórną kontrolą i narzuconą mieszkańcom strukturą przestrzenną parków i ogrodów. W ten sposób, dowodzą autorzy, budować można nowe relacje człowieka z miejskim ekosystemem i krajobraz zaangażowany, interakcyjny, aktywnie doświadczany, strukturyzowany i przeżywany, a nie jedynie kontemplowany. Immanentna koncepcja przestrzeni ${ }^{45}$ i lokalnego ekosystemu, wpisana w estetykę Białoszewskiego, okazuje się więc wyjątkowo nośna we współczesnych praktykach miejskich, gdy dzikość i naturalność zaczynają być poszukiwaną wartością, a alternatywne sposoby użytkowania miasta i myślenia o jego ekosystemie oraz o miejskiej antropologii środowiska stają się przedmiotem opracowań naukowych i starań aktywistów miejskich, mających też na uwadze alternatywne formy życia społecznego. Wszystkie one wypróbowywane były twórczo w pisarstwie i praktyce miejskiej Białoszewskiego.

Zaangażowane współtworzenie przestrzeni w praktykach Białoszewskiego jako użytkownika miejskiej przestrzeni opisałam szerzej w tekście Topo-Grafie (w) ruchu. Sztuka chodzenia Mirona Białoszewskiego, "Konteksty. Polska Sztuka Ludowa” 2015 nr 4, dowodząc zbieżności rekonstruowanej przeze mnie koncepcji przestrzeni Białoszewskiego z koncepcją antropologa środowiska Tima Ingolda. 


\section{Abstract}

\section{Agnieszka Karpowicz}

UNIVERSITY OF WARSAW

Miron Białoszewski's Wild Nature

In the second half of the 1970s, Miron Białoszewski lived in a block of flats on Lizbońska Street in Warsaw. His work from that period is dense with the names of flowers, trees, weeds, shrubs, as well as descriptions of practices related to them: collecting plants on the wild meadows and arranging them into spectacular bouquets in his flat, spontaneous outings to fetch flowers in the villages surrounding the city, buying flowers from street vendors. Karpowicz examines the wealth of plants in the poet's late work. This is contextualized with Białoszewski's output as a whole, his biography and topobiography, and finally the characteristics of urban spaces of his era. Karpowicz finally points out the coincidence between Białoszewski's aesthetic project and the most recent theoretical approaches to new ecosystems.

\section{Keywords}

urban flora, synanthropic plants, fourth nature, aesthetics of wastelands, Beata Gawryszewska, Maciej Łebkowski, economics of wastelands, Miron Białoszewski, Chamowo, Praga-Południe 